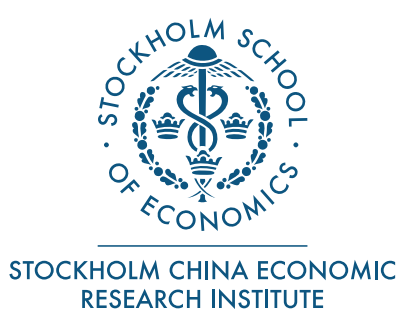

\title{
On the Challenge to Competitive Authoritarianism and Political Patronage in Malaysia
}

\author{
Anders C. Johansson \\ Stockholm School of Economics \\ Stockholm School of Economics Asia Working Paper \\ No. 29
}

February 2014 


\title{
On the Challenge to Competitive Authoritarianism and Political Patronage in Malaysia
}

\author{
Anders C. Johansson* \\ Stockholm School of Economics
}

February 2014

\begin{abstract}
*E-mail: anders.johansson@hhs.se. Financial support from the Ragnar Söderberg Foundation is gratefully acknowledged. Supply of data and support with information on political patronage by Effiezal Aswadi Abdul Wahab is highly appreciated. The author thanks Wing Thye Woo, Patrick Paul Walsh, Fredrik Sjöberg, and participants at the Asian Economic Panel Meeting in Dublin, September 2013, for helpful comments.
\end{abstract}




\title{
On the Challenge to Competitive Authoritarianism and Political Patronage in Malaysia
}

\begin{abstract}
In March 2008, Malaysia's political landscape was shaken by election results showing that the Barisan Nasional had won less than two thirds of the parliamentary seats and lost five states to the opposition. A two-thirds supermajority had been seen as a sacred threshold for the coalition to ensure its continued legitimacy. We conjecture that the 2008 election represented a challenge to the competitive authoritarian regime and that this had direct effects on firms with ties to the ruling coalition. Our empirical results show that firms with political patronage were adversely affected by the electoral outcome. More specifically, firms with close ties to the Barisan Nasional experienced a significant negative value effect. Firms characterized by political patronage also decreased their leverage levels significantly more than other firms after the 2008 election, suggesting that their access to debt capital had become more restricted. Moreover, this effect was mainly driven by changes in long-term debt. These results suggest a significant negative effect on connected firms as the political status quo was challenged in Malaysia.
\end{abstract}

JEL Classification: D72; G14; G30; G32; G38

Keywords: Competitive authoritarianism; Political patronage; Political connections; Firm performance; Capital structure; Debt maturity; Malaysia 


\section{Introduction}

This paper attempts to analyze the effects of the political changes following the 2008 general election in Malaysia on political patronage and the beneficial treatment of connected firms. In March 2008, Malaysia experienced a watershed in its political history. Once seen as the epitome of the competitive authoritarian state ${ }^{2}$, the election displayed how vulnerable the incumbent regime in Malaysia actually was. The ruling coalition Barisan Nasional won less than two thirds of the parliamentary seats and lost five states to the opposition. A two-thirds majority had been seen as a sacred threshold for the coalition to ensure its continued legitimacy (Berger, 2010). Only four years earlier, the Barisan Nasional had experienced its greatest victory ever, winning over 90 percent of the parliamentary seats. The 2008 election result set in motion an invigorated political debate, as it was no longer taken for granted that the ruling coalition would necessarily remain in power in the future. While the Barisan Nasional managed to hold on to power in the 2013 election, it has become apparent that the traditional form of competitive authoritarianism, a system where regimes present an illusion of multi-party democracy, is giving way to a new political reality in which the Barisan Nasional faces a significantly tougher challenge to hold on to power.

2 A competitive authoritarian state is a regime in which formal democratic institutions are viewed as principal means of obtaining and exercising political authority, but where the incumbent ruler violates the rules to such an extent that the state does not meet typical minimum standards for a democracy (Levitsky and Way, 2012). Related definitions of the political regime in Malaysia include "electoral authoritarianism" (e.g. Schedler, 2002, 2006), "semi-democracy" (Case, 1993, 1996), "semi-authoritarianism", (e.g. Carlson and Turner, 2009) and "soft authoritarianism" (Means, 1996). For a detailed analysis on competitive authoritarianism and a discussion on other definitions of similar regimes, see Levitsky and Way (2010). See also Greene (2010) for an interesting cross-country study on the political economy of authoritarian singleparty dominance. 
As the economic policy of the Malaysian leadership under then Prime Minister Mahathir Mohamad evolved, a number of companies controlled by people with close ties to the political leadership quickly became Malaysia's largest and most powerful firms. Being somewhat of a poster child for a stable political environment and long-standing relationships between business and politicians, the topic of political connections in Malaysia has been analyzed in a series of studies in the fields of economics and finance. However, these studies have primarily analyzed the status quo in Malaysian politics. This study takes a different direction in that it focuses on the change in political landscape during which competitive authoritarianism was truly challenged for the first time and what effects this event has had on firms with long-standing relationships with the incumbent coalition. We focus on two fundamental arguments. First, we believe that the failure of the ruling coalition in the 2008 election signaled a change in Malaysian politics, and thereby a change in the preferential treatment of firms with close connections to the Barisan Nasional. Second, we believe this change resulted in significant negative effects on the value of firms with political patronage and on their preferential access to debt financing. If this holds true, we would expect to find a significant effect on the stock performance and the capital structure of firms with political patronage. In addition to the overall effect on the debt level, related literature has shown that close ties to politicians may result in better access to long-term debt. We therefore take a closer look at the effect on debt maturity. Our results support all of these hypotheses. Analyzing cumulative abnormal returns surrounding the event, we find that the 2008 election had an immediate and significantly negative impact on the firm value of connected firms. This initial result supports that of an earlier study on the 2008 elections by Gul et al. (2009). Using a difference-in-difference 
approach to analyze the change in capital structure, we then find that connected firms exhibit less superior access to debt financing after the 2008 elections. We also find that most of the change in debt structure for firms characterized by political patronage was due to a significant change in long-term debt. Overall, the empirical results show that the challenge to competitive authoritarianism in Malaysia affected firms characterized by political patronage.

This study relates to a rich literature on political connections and rent seeking. In her early contribution to the study of rent seeking, Krueger (1974) argues that it is natural for firms to devote economic resources toward rent seeking in order to compete for favorable treatment. Politicians are often able to influence firms through different policy decisions, for political as well as for personal reasons (e.g., La Porta et al., 2002; Rajan and Zingales, 2003). Political decisions can influence firm's performance and ability to operate through a range of different channels, including preferential access to finance, superior access to government subsidies, preferential tax benefits, and the ability to work around formal regulatory constraints. ${ }^{3}$ A number of studies on this subject have focused primarily on the U.S. and other western countries (e.g. Roberts, 1990; Kroszner and Stratmann, 1998; Jayachandran, 2006; Knight, 2006; Ferguson and Voth, 2009; Benmelech and Moskowitz, 2010; and Cooper et al., 2010). Later studies have also looked at other countries around the world. Well-known examples include Fisman's (2001) analysis of firms that were connected to Indonesia's former dictator Suharto, Faccio's (2006) study on a large cross

3 The channel that has arguably been analyzed the most is preferential access to debt financing. Examples of such studies include: Dinc (2005) on a cross section of countries; Faccio et al. (2006) on the preferential treatment of firms that are close to bankruptcy across countries; Charumilind (2006) on Thailand; Johnson and Mitton (2003) on Malaysia; and Khwaja and Mian (2005) on Pakistan. A recent study by Feng et al. (2013) also identify a range of channels for preferential treatment of connected firms, including debt financing, tax benefits, subsidies, and access to regulated industries. 
section of countries, Fan et al.'s (2007) research on the effects of political connections on Chinese firms, and Claessens et al.'s (2008) examination of elections, campaign contributions and connected firms in Brazil. In the case of Malaysia, the most influential study is arguably that of Johnson and Mitton (2003), who analyzed how policy measures taken after the onset of the Asian financial crisis were used to benefit firms with close ties to the Barisan Nasional and Prime Minister Mahathir. A later study by Fraser et al. (2006) builds on Johnson and Mitton (2003) as it analyzes capital structure and political patronage in Malaysia. A few other studies have looked at related issues, including Adhikari et al. (2006), who study the effect of political connections on tax payments, and Bliss and Gul (2012a, 2012b), who look at political connections and the cost of debt and leverage. As mentioned earlier, the basic premise in most previous studies on Malaysia is a political status quo in which firms connected to the Barisan Nasional have been able to utilize different forms of preferential treatment. This study is different in that it focuses on the move away from that status quo and the effect this change may have on connected firms. It is thus closer to the earlier study by Fisman (2001), which shows that negative news of Suharto's health had a significantly negative effect on the value of connected firms in Indonesia.

The rest of this paper is organized as follows. Section 2 begins with a brief narrative of Malaysia politics since independence. It then ties the evolution of the political landscape to the development of patronage and corporate cronyism and, finally, explains the 2008 election and the significance of that event. The main purpose of this section is to shed light on some of the institutional features in the Malaysian economy that have provided for very strong ties between politicians and business leaders, as well as rent 
seeking. Section 3 introduces the data, explains how political patronage is identified, discusses the empirical methodology and formulates the research hypotheses. Section 4 presents and discusses the empirical results on firm value and Section 5 does the same for the results on capital structure. Section 6 then presents and discusses the results on debt maturity and links them to the findings on capital structure. Finally, Section 7 concludes the paper.

\section{Malaysian Politics: Ethnicity, Political Hegemony, and Patronage}

\subsection{A Brief Overview of the Malaysian People and Politics since Independence}

It has often been argued that Malaysia's multi-ethnic society is a product of British colonialism (e.g. Berger, 2010). While originally inhabited by what is commonly called bumiputera (literarily "Sons of the Soil"), i.e. Malays, and orang asli (a number of indigenous groups including Iban, Kadazan and Penan), immigrants started to arrive in large numbers during the period of British Malaya. Chinese immigrants came to work primarily in mining, commerce and trade, while Indians were mostly active on the plantations and in the lower levels of civil service (Crouch, 1996). As these additions to the population in what was to become Malaysia arrived quite late and during the time of colonization, they were usually called orang pendatang ("foreign person" or "immigrant") or pendatang asli ("foreign comer" or "foreign immigrant") by the Malays, who saw themselves as indigenous to the land.

The Federation of Malaya became independent from British colonial rule in 1957. In 1963, the country formally adopted the name Malaysia, which at the time included Malaya (peninsular Malaysia), Sabah, Sarawak, and Singapore. Independence was, to a 
large extent, achieved through collaborative efforts across ethnic lines. After this initial cooperation between different ethnicities, the introduction of elections in post-colonial Malayu led to the formation of the so-called Alliance. The Alliance was composed of the United Malays National Organisation (UMNO), the Malayan Chinese Association (MCA), and the Malayan Indian Congress (MIC). These parties and their coalition were run by what Jomo (1996) has labeled "elitist, multiethnic conservatives" or "moderate nationalists".

Singapore eventually exited the federation in 1965, at which point the Malaysia we know today was born. Before Singapore's separation from Malaysia, Lee Kuan Yew, leader of the Singapore-based People's Action Party (PAP), had proposed a "Malaysian Malaysia", where people regardless of ethnicity would have the same rights and be treated equally. This proposal stood in stark contrast to the concept of ketuanan Melayu ("Malay supremacy"), which focused on the special position of the indigenous Malays. Shamsul (2001) points out that it was colonial knowledge, inspired by social Darwinisim, that gave rise to the modern concept of the "Malay race" and bangsa, the "Malay nation", which rests on three pillars of "Malayness": bahasa, raja dan agama ("language, ruler and religion"). When Lee Kuan Yew's proposal was rejected, Singapore was expulsed from the federation and ethnic sentiments began to brew among both Malay and Chinese Malaysians.

As an increasing number of constituents grew increasingly dissatisfied with the three coalition parties, opposition parties began to gain ground. UMNO was challenged by PAS (Islamic Party of Malaysia), who became increasingly successful in attracting votes in certain areas. More importantly, the Democratic Action Party (DAP), a direct descendant of the PAP, and the Gerakan (Malaysian People's Movement) were formed in 1966 and 1968 and quickly began to attract support from urban non-Malays. In the elections on May 10, 
1969, the MCA lost a significant amount of support as the newly formed non-Malay parties gained two thirds of the urban vote (Hooker, 2003). The extent to which the MCA and MIC were unable to withstand the challenge from non-Malay parties was striking (Ratnam and Milne, 1970). The electoral outcome threatened the very fabric of the inter-communal basis of the Alliance. Tensions rose quickly among the ethnic groups and on May 13, 1969, it escalated into violence as supporters from both sides took to the streets. Violence continued until a State of Emergency was declared on May 15, 1969. The election results were thus overshadowed as people felt a need for order to be restored (Hooker, 2003).

As a direct result of the violence in May 1969, the way the political system functioned changed dramatically, away from consociationalism and towards UMNO hegemony (Berger, 2010). Control was seen as a necessity and the idea of ketuanan Melayu became the dominant force in national politics. A key instrument for this change was the New Economic Policy (NEP), a social engineering program with two distinct aims: to eradicate poverty and to restructure society to reach inter-ethnic economic parity between ethnic groups (Gomez and Jomo, 1998; Jomo and Gomez, 2000). In reality, the NEP developed into an affirmative action program for the bumiputera population, in which a Malay industrial and commercial social class was to be created and the living standards of bumiputera in general was to be raised (White, 2009). The NEP was in place from 1970 to 1990 and was then replaced by the so-called New Development Policy (NDP) in 1991, in most regards a continuation of the discriminatory practices against people from ethnic groups outside of the bumiputera.

As the old political system paved way for a new one, the Alliance was transformed into Barisan Nasional, a new coalition with a number of parties, of which UMNO, MCA and 
MIC are the three largest. Barisan Nasional has remained in power up until today and has effectively controlled the political process until 2008 through three key tactics: warnings of a constant risk of violence; the risk of political turmoil having a severe effect on the economy; and labeling dissenting political activities as uncivilized or rude (Berger, 2010).

\subsection{Political Patronage}

It is commonly argued that political patronage and cronyism in Malaysia developed as a result of the implementation of the NEP from the 1970s and forward. In an early study of the NEP and how it affected corporate life, Yoshihara (1988) stated that crony capitalists were private businessmen who reaped tremendous benefit from their close relationships with leading government officials. These businessmen enjoyed protection from foreign competition and different forms of preferential treatment, including government subsidies, concessions, licenses, and monopoly rights. ${ }^{4}$ It should be noted that there exists another strand of literature that instead focuses on the importance of the decolonization process and the early post-colonial period in forging close link between business leaders and politicians. As a proponent of this view, White (2009) argues that "the development of crony capitalism was concomitant with, and almost a function of, Alliance-led national integration". Given the discussion on the evolution of the Malaysian multi-ethnic society in the previous section, these two views are not necessarily contradictory, as the Alliance most likely set the framework for political patronage during the early post-colonial era and

4 While the primary focus of this paper is on the extraction of rents due to political patronage in Malaysia, it should be noted that the effects of the policies described here are not necessarily unilaterally negative. For example, while Chin and Jomo (2000) argue that the effects of government intervention in the banking sector and the redistribution of wealth has not been economically efficient, they acknowledge that inter-ethnic redistribution has likely "ensured a certain intangible, but nonetheless vital, political and hence economic stability, with positive consequences for economic development and industrial growth". 
the Barisan Nasional to a large extent institutionalized this feature in the domestic economy after the riots in 1969.

The most influential analysis of political patronage in Malaysia is arguably written by Gomez and Jomo (1998). They provide a detailed analysis of the evolution of the close links between the state and a group of favored business leaders during the 1970s as a result of the NEP and the effects this had on different industries and the domestic economy. In short, the NEP provided for new and more efficient ways for selected businesses to create and extract economic rents. The fact that business leaders with strong ties to leading politicians came to be the primary beneficiaries of government policies meant that involvement in politics soon became seen as a quick way for bumiputeras to get their hands on different business opportunities (Gomez and Jomo, 1998). ${ }^{5}$ It should be noted that even though a process of economic liberalization was initiated during the 1980s, political interventions in the private sector have been the norm up to this day (White, 2009). In line with this reality, Teh (2002) argues that Malaysia is a country where politicians and political parties are particularly prone to money politics and where the opportunities between the areas of politics and corrupt money are abundant. While political patronage arguably was at its highest during the time of Mahathir as the Prime Minister, the continued reliance on close connections to leading politicians is imperative for a group of large companies that expanded their operations quickly in the 1960s and 1970s.

${ }^{5}$ For a detailed account of a number of leading political capitalists and private entrepreneurs who have exploited their relationships with leading politicians, see Searle (1999). 


\subsection{The 2008 Election and the Challenge to Competitive Authoritarianism}

The emerging middle-class that evolved as a result of the NEP and the NDP was linked to the state through extensive patronage networks. This middle-class, composed of both Malay and Chinese Malaysians, naturally preferred a political status quo (Berger, 2010). However, while the Barisan Nasional continued to be in firm control of the elections after the incident in 1969, criticism against the Barisan Nasional government became increasingly widespread, especially during the 1990s. After the financial crisis spread from Thailand to Malaysia and other neighboring countries in 1997-1998, a movement known as reformasi took hold in Malaysia. Reformasi stood for something new, as it in many ways transcended ethnicity. Partly a result of modernization, there was an increasing overlap between interests and concerns of Chinese and Indian activists as well as Malays that felt that they were excluded from the system (Berger, 2010). Although these tendencies grew stronger in Malaysian society during the late 1990s and 2000s, the 2004 election was marked by an overwhelming victory by the Barisan Nasional, as the ruling coalition won over 90 percent of the parliamentary seats. The strong victory by the incumbent was most likely due to Mahathir stepping down (most of the criticism toward the Barisan Nasional had focused on his persona) and the fact the economy was rebounding.

While many observers felt that the 2004 elections had effectively put the reformasi movement to rest, the result of the 2008 elections would come to show that this assumption was wrong. In 2007, the so-called Bersih coalition gained momentum. Bersih was a coalition of NGOs that worked for reform of the electoral system and for clean and free elections. In November 2007, the coalition arranged a public demonstration in Kuala Lumpur, an event that is often tied to the shift in public sentiment in the 2008 election. 
While the opposition was expected to win more votes than the previous election, the results in March 2008 surprised the whole country, as well as foreign observers. The opposition coalition, Pakatan Rakyat (PR, or the People's Alliance) with the three leading opposition parties, the Democratic Action Party (DAP), the Pan-Malaysian Islamic Party (PAS), and Parti Keadilan Rakyat (PKR) won 82 out of 222 parliamentary seats and the control of five of the twelve state legislatures. As a two-thirds supermajority had been regarded as a sacred threshold for the Barisan Nasional to ensure its continued legitimacy, the election results were a disaster for the ruling coalition. For the first time, a real challenge to the competitive authoritarian rule in Malaysia had presented itself.

\section{Data and Methodology}

\subsection{Data}

The empirical analysis in this paper utilizes two sets of data. The first one focuses on identifying political patronage and is explained in more detail in the following section. The second data set comes from the Capital IQ database, which provides detailed financial information on listed companies. Capital IQ does not include all listed firms in Malaysia, but was the most comprehensive database that we could find for this study. For the firm value analysis, we use daily closing prices for individual stocks and the market index, also from Capital IQ.

For the analysis of capital structure and debt maturity, we use annual financial data for the period 2005-2011. If a firm has missing observations for any of the dependent or explanatory variables, we have eliminated that firm from the data set. For the empirical analysis on capital structure and debt maturity, we divide the analysis into two parts. In the 
first part, we include all firms regardless of industry. We do this because we want to be able to compare our results to those of Fraser et al. (2006), who include all industries in their main analysis. We are aware of the fact that the typical capital structure in the financial sector differs from that of other industries, which is the main reason why financial firms are most often excluded from studies on capital structure. We therefore also conduct a separate analysis on capital structure and debt maturity in which we exclude all financial firms in the data set.

\subsection{Identifying Political Patronage 6}

Previous studies have used numerous ways to gauge firms' political connections. In this study, we make use of earlier research on political patronage in Malaysia. More specifically, we use the data on political connections found in Johnson and Mitton (2003) (similar data are found in Faccio, 2006). Their data on political patronage originates from Gomez and Jomo (1998), who provide a detailed study on the political economy of Malaysia and a comprehensive discussion on politically connected firms going back to the beginning of the NEP. In essence, the list of connected firms provided by Johnson and Mitton (2003) is composed of a group of firms controlled by business leaders with informal but strong ties to power politicians during the 1990s.

One could argue that these long-standing relationships are bound to change. To some extent, this is true. As most things change, so do firms and the people who lead them. This is one of the reasons for why this study does not include all the firms listed in Johnson and Mitton (2003) or Faccio (2006). However, the primary focus here is to shed light on the

${ }^{6}$ The author is grateful to Effiezal Aswadi Abdul Wahab for providing the information on firms characterized by political patronage. 
effects of the challenge to the competitive authoritarian state led by the Barisan Nasional since before the beginning of the NEP. Politics and business have been remarkably stable in Malaysia for several decades. As mentioned earlier, one of the ruling coalition's key strategies for remaining in power has been to advocate the need for political stability for continued economic development, and to some extent this has held true: Malaysia managed to maintain an impressive level of economic growth for several decades leading up to the financial crisis that engulfed several of the countries in the region in the late 1990s. In line with this reasoning, Johnson and Mitton (2003) argue that using the data based on the analysis of Gomez and Jomo (1998) does not represent an issue as the government was stable throughout the period in their analysis. Fraser et al. (2006) argue the same and add that it takes a long time to foster political relationships like these in the non-western world and that they are not very likely to change abruptly. We agree with these arguments. Our assumption is that certain business leaders managed to build long-standing relationships with the ruling coalition over an extended period of time. As such, they are likely to last unless something significant happens in each individual case. It is thus the change to the political system in Malaysia that is of importance, rather than the change in the relationship between business leaders and politicians.

Due to the somewhat limited data set used in this study, we have attempted to identify additional ties between politicians and firms. It can easily be argued that firms directly controlled by the government have strong and direct ties to leading politicians and the Barisan Nasional. We therefore look at Khazanah Nasional Berhad, the investmentholding vehicle of the Malaysian government for additional information on political patronage. Khazanah holds and manages commercial assets on behalf of the government. 
The ruling coalition is in firm control of Khazanah, with Najib Tun Razak, the current Prime Minister and the President of UMNO, sitting as Chairman of its Board of Directors. We therefore run additional tests in which we also include listed firms that we identify as being controlled by Khazanah.

\subsection{Research Hypotheses}

The main outcome in most previous studies on firms and political connections indicate that firms are able to increase their firm value as a result of their close ties with leading politicians. Previous studies have shown this to be the case also for Malaysian firms. For example, Johnson and Mitton (2003) find that firms related to Prime Minister Mahathir experienced significant abnormal firm value increases following the introduction of capital controls after the onset of the Asian financial crisis. Similarly, Hassan et al. (2012) find that the value of connected firms in Malaysia increases as a result of favorable political events. If we believe the conjecture that the 2008 election posed a significant challenge to the traditional competitive authoritarian state, with Barisan Nasional at the helm, we would expect that this event had a significant effect on the value of firms characterized by political patronage.

Hypothesis 1: Firms with ties to the ruling coalition experienced a significant negative effect on their market value as the outcome of the 2008 election was announced

It has been argued that capital structure is not only dependent on firm-specific and macroeconomic determinants, but also country-specific factors. Rajan and Zingales (1995) stress the link between institutions and capital structure. Previous studies on connections 
and capital structure have shown that connected firms tend to have better access to debt financing and exhibit higher levels of leverage compared to normal firms. For example, La Porta (2003) shows that related firms tend to obtain much better terms than other firms in Mexico. Khwaja and Mian (2005) find that connected firms in Pakistan borrow 45 percent more than other firms. In the case of Malaysia, Johnson and Mitton (2003) discuss the fact that politically connected firms seem to have better access to debt financing. In a study that focuses on the effects of political connections on the capital structure of Malaysia firms, Fraser et al. (2006) find a significant and positive relationship between leverage and different measures of political patronage. Similarly, Bliss and Gul (2012b) find a significant and positive association between political connections and leverage in Malaysia. Again, if we believe that the 2008 election represented a significant challenge to the Barisan Nasional's rule, we can expect that the election outcome had a significant and negative effect on the capital structure of firms characterized by political patronage:

Hypothesis 2: Firms with ties to the ruling coalition experienced a significant negative effect on their level of leverage as a result of the 2008 election

Finally, we want to shed light on how the composition of debt was affected by the election outcome. Charumilind et al. (2006) show that Thai firms with political connections had better access to long-term financing compared to other Thai firms before the Asian financial crisis. Feng et al. (2013) also find that firms controlled by business owners who enter into high-level politics in China experienced a significant positive effect on debt maturity. In an event study that uses a methodology similar to ours, Fan et al. (2008) show 
that firms with connections to corrupt bureaucrats experienced a significant decline in debt maturity ratios after corruption cases of the bureaucrats became public. These studies suggest that political patronage can be used to obtain loans with longer maturity and we thus base our third hypothesis on this premise:

Hypothesis 3: Firms with ties to the ruling coalition experienced a significant negative effect on their long-term debt level as a result of the 2008 election

\section{Effects on Firm Value}

We begin the empirical analysis with an inspection of firm value effects after the announcement of the election results. To do this, we use an event study approach in which 10 March 2008 is set as time zero (the elections were held on Saturday, 8 March, making 10 March 2008 the closest trading day). It is possible to add additional event dates. For example, Gul et al.'s (2009) preliminary study on short-term effects after the election include three additional dates with events related to the election (two mass demonstrations and the announcement of the general election and that the parliament had been dissolved). However, the goal here is to keep the analysis as clean as possible and not add potential noise to the regressions. As have been noted before, it was relatively clear that the Barisan Nasional would perform somewhat worse in 2008 compared to the 2004 election. However, the announcement of the election results surprised the nation and we therefore expect a significant effect on firm value if the conjecture that the election outcome marked a change in the status quo of the political landscape holds. 
We thus begin with standard calculations of cumulative abnormal returns (CARs) to see if there is a significant short-term effect on firm value. A market-adjusted return (index) model is used to capture the abnormal returns. ${ }^{7}$ The abnormal returns are calculated as:

$$
A R_{i t}=R_{i t}-E\left(R_{i t}\right)
$$

where $R_{i t}$ is the daily return on the stock of firm $i$ at day $t$, and $E\left(R_{i t}\right)$ is the expected return, measured by the market return in the market-adjusted return model. The CAR for firm $i$ is then calculated as:

$$
C A R_{i t}=\frac{1}{N} \sum_{i=1}^{N} A R_{i t} .
$$

Finally, the average CAR for the sample is calculated by aggregating the CARs for all sample firms and then taking the mean of that value.

The CARs for different event windows are shown in Table 1. As we use CAR to analyze effects on the stock price, we use relatively short event windows, ranging from ($1,1)$ to $(-1,10)$. The upper half of the table presents the CARs when using Johnson and Mitton's (2003) list of connected firms, while the lower half presents the results using the list that also includes firms controlled by Khazanah. Columns one and two present the CARs for firms with and without political patronage, respectively, while the third column shows

\footnotetext{
${ }^{7} \mathrm{~A}$ market model was also tested, with the results remaining qualitatively the same.
} 
the difference in the CARs of the two firm samples. The CARs for the different subsamples suggest that firms characterized by political patronage performed worse than normal listed firms after the announcement of the election results. The difference between the two groups is significant across all event windows and regardless of the measure of political patronage used. These initial results demonstrate that firms with ties to the ruling coalition experienced a significant negative effect on firm value as a result of the election. ${ }^{8}$

\section{[TABLE 1 ABOUT HERE]}

To analyze whether the difference in firm value changes is driven by political patronage, we control for typical firm-specific variables. To do so, the following variables which are typically included in the analysis of firm performance are used: Size, measured as the natural logarithm of total assets; ROA, the return on assets, measured as earnings before interest and taxes (EBIT) over total assets; Growth, measured as market value over book value; and Tangible Assets, measured as net property, plant, and equipment over total assets. Summary statistics for each of the explanatory variables are presented in Table 2. Again, the sample is divided into two groups based on the definition of political patronage discussed earlier. For the first measure, the sample includes 39 firms characterized by political patronage and 693 regular firms. Correspondingly, the second measure gives a sample of 45 and 687 firms, respectively. The most notable difference between the two groups is firm size. Firms with political patronage are significantly larger than firms without such connections. This is to be expected, as firms with political patronage in

${ }^{8}$ These initial results support those of Gul et al. (2009), who found a significant negative effect on connected firms after the 2008 election. 
Malaysia hold key positions in their respective industries and have been able to expand their business significantly making use of their close ties to the political leadership over several decades. This also indicates that it is important to control for difference in size with a multivariate regression instead of focusing only on the differences in the mean of CARs between the two groups. Growth is also somewhat higher for firms with political patronage, while difference in the other explanatory variables is insignificant.

\section{[TABLE 2 ABOUT HERE]}

Table 3 shows the correlation among the CARs and the control variables. The correlation between the explanatory variables is low, suggesting that multicollinearity does not pose a problem in the data set. The only variable that exhibits a somewhat higher correlation with political patronage is that of firm size. There is a high level of correlation between the two different measures of political patronage. This is to be expected, as the second measure is primarily composed of firms that are included in the first measure. The two measures for political patronage will only be used as alternatives and not together in the same regression.

\section{[TABLE 3 ABOUT HERE]}

The multivariate regression model used to analyze the effects of political patronage on firm value after the 2008 election is written out in Equation 3S. The main explanatory variable in the model is that of political patronage. $\mathbf{X}_{i}$ includes the other 
explanatory variables discussed above and a dummy to control for industry effects. Moreover, as Fraser et al. (2006) include interaction terms in their analysis of political connections and leverage in Malaysia, interaction terms between political patronage and the other explanatory variables are included here as well. The model is estimated using robust standard errors.

$$
C A R_{i}=\alpha_{i}+\beta_{i} \cdot \text { patronage }+\gamma_{i} \cdot \mathbf{X}_{i}+\varepsilon_{i}
$$

Table 4 presents the results of the multivariate regression with the first measure of political patronage included in the model. Here, CARs for four different event windows are used as the dependent variable (one, three, five, and ten days after the event). The effect of political patronage on firm value is negative on all four time horizons. The effect is too weak to be significant in the shortest event window, but significant in all of the other windows. This suggests that the effect is not a first-day occurrence, but that it grew stronger during the week after the announcement of the results. The effect of firm size is also significant and negative in the three longer event windows. Moreover, the interaction term between political patronage and firm size is significant in these three regressions, indicating that the effect of political patronage is dependent on firm size.

\section{[TABLE 4 ABOUT HERE]}

We then estimate the same regression model using the alternative measure of political patronage. The regression results, which are shown in Table 5, mirror those in 
Table 4. Again, political patronage has a significant negative effect on firm value for the three longer event windows. Firm size has a significant negative effect on firm value and the interaction term patronage*size is once more significant for the three longer event windows.

The results in this section suggest that the choice of measurement for political patronage does not affect the main results in the analysis. We can conclude that the announcement of the 2008 election had a significant and negative effect on the value of firms with close ties to the ruling coalition. These results support the conjecture that the election results represented a shift in the political landscape characterized by a challenge to the competitive authoritarian regime that has governed the country since 1969.

\section{[TABLE 5 ABOUT HERE]}

\section{Effects on Capital Structure}

The previous section provided empirical evidence that firms characterized by political patronage were adversely affected by the announcement of the 2008 election results. The next step in the analysis is to attempt to identify a channel for preferential treatment that may have been affected by the political changes that year. As previous studies in the literature on political connections have shown that access to debt financing and resulting higher leverage ratios is a common channel through which connected firms exploit their ties to politicians, this section focuses on the potential effect that the election had on capital structure. 
To analyze these potential changes, we follow the literature (e.g. Harris and Raviv, 1991; Rajan and Zingales, 1995) and use leverage as a proxy for capital structure. Here, we define leverage as total debt (i.e. both short-term and long-term debt) over total assets. To analyze the effects that the 2008 election had on firms' capital structure, we use a difference-in-difference approach. We thus define change in leverage as the difference between the average annual level of leverage three years before the event and the average annual level of leverage three years after the event. By using a difference-in-difference approach, we are able to address some of the potential endogeneity issues found in other cross-sectional studies (Fan et al., 2008, Feng et al., 2013; Johansson and Feng, 2013).

Equation 4 shows the multivariate regression model that is used to analyze the effects of political patronage on the change in leverage after the 2008 election. The dependent variable is the change in average annual leverage and the main explanatory variable is again political patronage. Variables typically found in the literature on capital structure are added to control for firm-specific factors. Similar to the regression analysis on CARs in the previous section, size, ROA, growth and tangible assets are again included in the model. We also include the leverage level at the end of 2008 to control for the general level of leverage at the time of the election. Dummies for industry effects are also included but not reported. Finally, interaction variables between political patronage and each of the explanatory variables are included for completeness. To stay as close as possible to the analysis on political patronage and capital structure in Malaysia by Fraser et al. (2006), we first perform an analysis in which we include financial firms.

$$
\text { Dleverage }_{i}=\alpha_{i}+\beta_{i} \cdot \text { patronage }+\gamma_{i} \cdot \mathbf{X}_{i}+\varepsilon_{i}
$$


Table 6 presents the results of the multivariate regressions with change in leverage as the dependent variable. The first column provides the estimation results using the first measure of political patronage as the main explanatory variable, while the second column presents the results for the regression in which the alternative second measure of political patronage is used. The firm sample is now somewhat smaller compared to that in the stock performance in the previous section, with a total of 664 firms. The difference in sample size is due to differences in data availability for some of the financial variables. Focusing on the primary explanatory variable, we see a significant and negative relationship between political patronage and change in leverage. The effect is significant regardless of which of the two types of measures for political patronage used in the estimation. As for the other explanatory variables, tangible assets and growth have a significant and positive effect on the change in leverage, while the other variables are insignificant. The interaction variable between political patronage and firm size has a significant effect in the first regression, but not in the second.

The significant and negative effect of political patronage on change in leverage supports the hypothesis that leverage is closely associated with political patronage and that the change in the political landscape after the 2008 election resulted in a decreased ability for firms with political patronage to maintain abnormally high leverage levels. Indirectly, the results are also corroborating those of earlier studies on capital structure and political patronage in Malaysia (Fraser et al., 2006 and Bliss and Gul, 2012b).

[TABLE 6 ABOUT HERE] 
Most studies on capital structure exclude financial firms (e.g. Bradley et al., 1984; Friend and Lang, 1988). For robustness, we therefore run additional tests using a sample without financial firms. The regression model in Equation 4 remains the same. The results of the new regressions are presented in Table 7. The sample is now smaller, with a total of 557 firms. Looking at the first regression, with the standard measure of political patronage, the effect of political patronage on the change in leverage is still significant and negative. The results in the second column suggest that the effect is somewhat weaker when the alternative measure of political patronage, which also incorporates firms controlled by Khazanah, is used. However, the effect of political patronage is still significant at the 10 percent level.

We can thus conclude that there is a significant and negative relationship between political patronage and change in leverage after the 2008 election. This finding supports the hypothesis that firms with strong ties to the ruling coalition in Malaysia are dependent on a status quo in the political landscape. As the competitive authoritarian rule of the Barisan Nasional was challenged, it had a direct and significant effect on the ability to secure abnormal levels of debt financing for firms with political patronage. The effect on the preferential treatment in the form of superior access to debt financing is important and provides for an explanation to why the value of firms with political patronage was negatively affected after the announcement of the election results in March 2008.

[TABLE 7 ABOUT HERE] 


\section{Effects on Debt Maturity}

Having established that there is a significant negative effect of political patronage on leverage after the 2008 election, we now take a closer look at the potential effect on the structure of debt. More specifically, we want to see if the negative effect is driven by changes in long-term debt, as previous studies have shown that politically connected firms typically have better access to debt financing with longer maturity (e.g. Charumilind et al., 2006 and Feng et al., 2013). To analyze the potential effects of the 2008 election, we again use a difference-in-difference approach in which the dependent variable now is the change in long-term debt. To complete the analysis on debt maturity, we also run regressions in which change in short-term debt is the dependent variable. The debt variables are the change in the three-year average of short- and long-term debt over total assets, respectively, and the empirical models can be written as:

$$
\begin{aligned}
& \Delta l t d_{i}=\alpha_{i}+\beta_{i} \cdot \text { patronage }+\gamma_{i} \cdot \mathbf{X}_{i}+\varepsilon_{i}, \\
& \Delta s t d_{i}=\alpha_{i}+\beta_{i} \cdot \text { patronage }+\gamma_{i} \cdot \mathbf{X}_{i}+\varepsilon_{i},
\end{aligned}
$$

where $\Delta l t d_{i}$ and $\Delta s t d_{i}$ is the change in the annual average of long- and short-term debt, respectively. The key explanatory variable is again the measure of political patronage, while the remaining explanatory variables are the same as the ones included in the analysis on leverage in the previous section.

We once more run the analysis on the full sample as well as the sample without financial firms. Table 8 presents the results for the full sample, with the regressions on the 
change in long-term debt using the two different measures for political patronage in the first two columns, and the regressions on the change in short-term debt in the following two columns. Looking first at the effects on long-term debt in Column 1, the coefficient for political patronage is negative and significant at the $1 \%$ level. Similarly, when using the alternative measure for political patronage in Column 2, the coefficient for political patronage remains negative and significant at the $1 \%$ level. These results support the hypothesis that firms with close ties to the ruling coalition experienced a significant negative effect on their long-term debt after the 2008 election.

Next, we want to know if connected firms experienced a similar effect on their short-term debt financing. Column 3 in Table 8 shows that this is not the case. While the coefficient for political patronage is negative, it is also statistically insignificant. The results in Column 4 show that this result is not dependent on how we define political patronage. When we include the firms in which Khazanah Nasional Berhad has a significant ownership, the effect on the change in short-term debt remains statistically insignificant. These findings support previous studies on preferential access to long-term debt financing by politically connected firms and shed light on the way capital structure changed for firms characterized by political patronage after the 2008 election.

\section{[TABLE 8 ABOUT HERE]}

To once more control for the fact that financial firms typically have very different capital structures compared to other firms, we run additional regressions in which we exclude all financial firms. The empirical results are presented in Table 9. We again find 
that the change in long-term debt is negatively associated with political patronage. The effect is somewhat more modest, but the coefficient for political patronage is still significant at the $5 \%$ level. Moreover, the coefficient for political patronage is statistically insignificant in the regressions on change in short-term debt. These results again suggest that it is the change in long-term debt that is driving the effects on capital structure that we found in the previous section.

\section{[TABLE 9 ABOUT HERE]}

\section{Conclusion}

In March 2008, Malaysia's political landscape was shaken as the election results showed that the ruling coalition had won less than two thirds of the parliamentary seats and lost five states to the opposition. The premise of this paper has been that this event marked the beginning of a transformation from a strong competitive authoritarian state to a political system in which the victor of future elections is not self-evident. As Malaysia has been the focus of several studies on political connections and their value for firms, it is particularly suitable for an analysis on changes in the political landscape and its effect on connected firms. The aim of this paper has thus been to investigate and identify the effects of the challenge to the Malaysian competitive authoritarian state on firms characterized by their political patronage.

The empirical analysis in this study shows that firms with political patronage were adversely affected by the electoral outcome. More specifically, firms with close ties to the 
Barisan Nasional experienced a significant negative value effect compared to other firms listed on the Malaysian stock exchange. Furthermore, we show that firms with political patronage decreased their leverage levels significantly more than other firms after the 2008 election. Our empirical findings also suggest that access to long-term debt acted as the main driver behind the effect on leverage, supporting the theory that firms characterized by political patronage lost some of the their superior access to long-term debt financing after the election. These results provide evidence of a significant negative effect towards politically connected firms in Malaysia as the political status quo was challenged.

An underlying premise for the analysis in this paper is that relationships to leading politicians are valuable for business leaders, but that this value is directly dependent on political control. While political connections have proven to be of substantial value for firms in both developed and developing countries, it is likely to be more valuable in countries with relatively poorly developed institutions. This is supported by previous studies. For example, looking at politically connected firms in China, Johansson and Feng (2013) find that political connections are significantly more valuable in regions with less developed local institutions. Malaysia constantly ranks very low in terms of institutions, governance, and corruption. One example of this is Transparency International's corruption index, in which Malaysia ranked 54 in 2012. The same year, the country scored worst in terms of bribes, indicating that bribery is likely systemic and institutionalized in the country (Ng, 2012).

It is likely that, as the semi-authoritarian regime in Malaysia is being challenged, the Barisan Nasional will be forced to change its modus operandi to remain in power. 
Advances in information technology, as well as economic development and the expanding middle-income class, brings with it the need for changes not only to the political system but also to the domestic economy. While the Barisan Nasional was previously able to rely on the promise of political stability and continued economic development for its continued rule, the challenge presented by the 2008 election result suggests that the continued focus on selected business leaders and the ethnically slanted economic policies need to be replaced by something else. If this political scenario continues to play out, the old form of political patronage that traces back to the NEP, and even the post-colonial period, will most likely continue to decrease in value. 


\section{References}

Adhikari, A., Derashid, C., Zhang, H., 2006. Public policy, political connections, and effective tax rates: Longitudinal evidence from Malaysia. Journal of Accounting and Public Policy 25, 574-595.

Benmelech, E., Moskowitz, T., 2010. The political economy of financial regulation: Evidence from U.S. state usury laws in the 19th Century. Journal of Finance 65, 1029-1073.

Berger, D., 2010. The 2008 Malaysia general election: Killing the ghost of 1969? AsiaOnline: Flinders Asia Centre Occasional Paper 2, April 2010.

Bliss, M.A., Gul, F.A., 2012a. Political connection and cost of debt: Some Malaysian evidence. Journal of Banking and Finance 36, 1520-1527.

Bliss, M.A., Gul, F.A., 2012b. Political connection and leverage: Some Malaysian evidence. Journal of Banking and Finance 36, 2344-2350.

Booth, L., Aivazian, V., Demirguc-Kunt, A., Maksimovic, V., 2001. Capital structures in developing countries. Journal of Finance 56, 87-130.

Bradley, M., Jarrell, G.A., Kim, E.H., 1984. On the existence of an optimal capital structure: Theory and evidence. Journal of Finance 39, 857-878.

Carlson, M., Turner, M., 2009. Popular perceptions of political regimes in East and Southeast Asia. Democratization 16, 377-398.

Case, W., 1993. Semi-democracy in Malaysia: Withstanding the pressures for regime change. Pacific Affairs 66, 183-205.

Case, W., 1996. Can the 'halfway house' stand? Semidemocracy and elite theory in three Southeast Asian countries. Comparative Politics 28, 437-464.

Charumilind, C., Kali, R., Wiwattanakantang, Y., 2006. Connected lending: Thailand before the financial crisis. Journal of Business 79, 181-218.

Chin, K.F., Jomo, K.S., 2000. Financial sector rents in Malaysia. In Khan, M.H., Jomo, K.S. (eds.), Rents, rent-seeking and economic development: Theory and evidence in Asia. Cambridge: Cambridge University Press. 
Claessens, S., Feijen, E., Laeven, L., 2008. Political connections and preferential access to finance: The role of campaign contributions. Journal of Financial Economics 88, 554-580.

Cooper, M.J., Gulen, H., Ovtchinnikov, A.V., 2010. Corporate political contributions and stock returns. Journal of Finance 65, 687-724.

Dinc, I.S., 2005. Politicians and banks: Political influence on government-owned banks in emerging markets. Journal of Financial Economics 77, 453-479.

Faccio, M., 2006. Politically connected firms. American Economic Review 96, 369-386.

Faccio, M., Masulis, R.W., McConnell, J.J., 2006. Political connections and corporate bailouts. Journal of Finance 61, 2597-2635.

Fan, J.P.H., Rui, O.M., Zhao, M., 2008. Public governance and corporate finance: evidence from corruption cases. Journal of Comparative Economics 36, 343-364.

Fan, J.P.H., Wong, T.J., Zhang, T., 2007. Politically connected CEOs, corporate governance, and post-IPO performance of China's newly partially privatized firms. Journal of Financial Economics 84, 330-357.

Feng, X., Johansson, A.C., Zhang, T., 2013. Mixing business with politics: Political participation by entrepreneurs in China. Stockholm School of Economics Asia Working Papers No. 2013-28.

Ferguson, T., Voth, H.-J., 2008. Betting on Hitler - The value of political connections in Nazi Germany. Quarterly Journal of Economics 123, 101-137.

Fisman, R., 2001. Estimating the value of political connections. American Economic Review 91, 1095-1102.

Fraser, D.R., Zhang, H., Derashid, C., 2006. Capital structure and political patronage: The case of Malaysia. Journal of Banking and Finance 30, 1291-1308.

Friend, I., Lang, L.H.P., 1988. An empirical test of the impact managerial self-interest on corporate capital structure. Journal of Finance 43, 271-281.

Goldman, E., Rocholl, J., So, J., 2009. Do politically connected boards affect firm value? Review of Financial Studies 22, 2331-2360. 
Gomez, E.T., Jomo, K.S., 1999. Malaysia's political economy: Politics, patronage and profits, $2^{\text {nd }}$ Edition. Cambridge: Cambridge University Press.

Greene, K.F., 2010. The political economy of authoritarian single-party dominance. Comparative Political Studies 43, 807-834.

Gul, F.A., Fung, S.Y.K., Radhakrishnan, S., 2009. Malaysian government election losses, political connections and equity values: A test of the "surviving elite" hypothesis. Hong Kong Polytechnic University, unpublished manuscript.

Harris, M., Raviv, A., 1991. The theory of capital structure. Journal of Finance 46, 297-355.

Hooker, V.M., 2003. A short history of Malaysia: Linking east and west. Crows Nest, NSW: Allen \& Unwin.

Jayachandran, S., 2006. The Jeffords effect. Journal of Law and Economics 49, 397-425.

Johansson, A.C., Feng, X., 2013. The state advances, the private sector retreats: Firm effects of China's great stimulus program. Stockholm School of Economics Asia Working Papers No. 2013-25.

Johnson, S., Mitton, T., 2003. Cronyism and capital controls: Evidence from Malaysia. Journal of Financial Economics 67, 351-382.

Jomo K. S., 1996. Elections' Janus face: Limitations and potential in Malaysia, in Taylor, R.H. (ed.), The politics of elections in Southeast Asia. Washington, DC: Woodrow Wilson Center Press.

Jomo, K.S., Gomez, E.T., 2000. The Malaysian development dilemma. In Khan, M.H., Jomo, K.S. (eds.), Rents, rent-seeking and economic development: Theory and evidence in Asia. Cambridge: Cambridge University Press.

Khwaja, A., Mian, A., 2005. Do lenders favor politically connected firms? Rent provision in an emerging financial market. Quarterly Journal of Economics 120, 1371-1411.

Knight, B., 2006. Are policy platforms capitalized into equity prices? Evidence from the Bush/Gore 2000 presidential election. Journal of Public Economics 90, 751-773.

Kroszner, R. S., Stratmann, T.E., 1998. Interest-group competition and the organization of Congress: Theory and evidence from financial services' political action committees. American Economic Review 88, 1163-1187. 
Krueger, A., 1974. The political economy of the rent-seeking society. American Economic Review 64, 291-303.

La Porta, R., 2003. Related lending. Quarterly Journal of Economics 188, 231-268.

La Porta, R., Lopez-de-Silanes, F., Shleifer, A., Vishny, R., 2002. Investor protection and corporate valuation. Journal of Finance 57, 1147-1170.

Levitsky, S., Way, L., 2010. Competitive authoritarianism: Hybrid regimes after the Cold War. New York: Cambridge University Press.

Levitsky, S., Way, L., 2012. The rise of competitive authoritarianism. Journal of Democracy 13, 51-65.

Means, G.P., 1996. Soft authoritarianism in Malaysia and Singapore. Journal of Democracy 7, 103-117.

Ng, J., 2012. Malaysia tops bribery table. Wall Street Journal Online, 11 December 2012.

Rajan, R., Zingales, L., 1995. What do we know about capital structure? Some evidence from international data. Journal of Finance 50, 1421-1460.

Rajan, R., Zingales, L., 2003. The Great Reversals: The politics of financial development in the 20th century. Journal of Financial Economics 69, 5-50.

Ratnam, K.J., Milne, R.S., 1970. The 1060 parliamentary election in West Malaysia. Pacific Affairs 43, 203-226.

Roberts, B., 1990. A dead senator tells no lies: Seniority and the distribution of Federal benefits. American Journal of Political Science 34, 31-58.

Schedler, A., 2002. The menu of manipulation. Journal of Democracy 13, 36-50.

Schedler, A., 2006. The logic of electoral authoritarianism. In Schedler, A. (ed.), Electoral authoritarianism. The dynamics of unfree competition. Boulder: Lynne Rienner.

Searle, P., 1999. The riddle of Malaysian capitalism: Rent-seekers or real capitalists? Honolulu, HI: Asian Studies Association of Australia in association with Allen \& Unwin and University of Hawai'i Press 
Shamsul, A.B., 2001. A history of an identity, an identity of a history: The idea and practice of 'Malayness' in Malaysia reconsidered. Journal of Southeast Asian Studies 32, 355-366.

Teh, Y.K., 2002. Money politics in Malaysia. Journal of Contemporary Asia 32, 338-345.

White, N.J., 2009. The beginnings of crony capitalism: Business, politics and economic development in Malaysia, c. 1955-70. Modern Asia Studies 38, 389-417.

Yoshihara, K., 1998. The rise of ersatz capitalism in South-East Asia. Singapore: Oxford University Press. 


\section{Table 1. Cumulative Abnormal Returns}

Political Patronage 1

\begin{tabular}{lccc}
\hline $\begin{array}{l}\text { Event } \\
\text { Window }\end{array}$ & $\begin{array}{c}\text { Firms with Political Patronage } \\
(\mathrm{n}=39)\end{array}$ & $\begin{array}{c}\text { Firms without Political Patronage } \\
(\mathrm{n}=754)\end{array}$ & $\begin{array}{c}\text { Difference in CARs } \\
\text { (Significance with } t \text {-statistics) }\end{array}$ \\
\hline$(-1,1)$ & 0.003 & 0.034 & $0.032^{* *}$ \\
& $(0.079)$ & $(0.101)$ & $(1.924)$ \\
$(-1,2)$ & -0.005 & 0.024 & $0.029^{* *}$ \\
& $(0.075)$ & $(0.099)$ & $(1.807)$ \\
$(-1,3)$ & -0.014 & 0.034 & $0.048^{* * *}$ \\
& $(0.083)$ & $(0.108)$ & $(2.738)$ \\
$(-1,4)$ & -0.008 & 0.034 & $0.042^{* * *}$ \\
& $(0.087)$ & $(0.108)$ & $(2.369)$ \\
$(-1,5)$ & -0.015 & 0.030 & $0.045^{* *}$ \\
& $(0.101)$ & $(0.130)$ & $(2.109)$ \\
$(-1,10)$ & -0.024 & 0.015 & $0.039^{* *}$ \\
& $(0.103)$ & $(0.123)$ & $(1.922)$ \\
\hline
\end{tabular}

Political Patronage 2

\begin{tabular}{lccc}
\hline $\begin{array}{l}\text { Event } \\
\text { Window }\end{array}$ & $\begin{array}{c}\text { Firms with Political Patronage } \\
(\mathrm{n}=45)\end{array}$ & $\begin{array}{c}\text { Firms without Political Patronage } \\
(\mathrm{n}=748)\end{array}$ & $\begin{array}{c}\text { Difference in CARs } \\
\text { (Significance with } t \text {-statistics) }\end{array}$ \\
\hline$(-1,1)$ & 0.003 & 0.035 & $0.032^{* *}$ \\
& $(0.075)$ & $(0.101)$ & $(2.089)$ \\
$(-1,2)$ & -0.006 & 0.024 & $0.030^{* *}$ \\
& $(0.071)$ & $(0.099)$ & $(1.994)$ \\
$(-1,3)$ & -0.014 & 0.035 & $0.049 * * *$ \\
& $(0.080)$ & $(0.108)$ & $(2.991)$ \\
$(-1,4)$ & -0.010 & 0.034 & $0.044^{* * *}$ \\
& $(0.083)$ & $(0.109)$ & $(2.682)$ \\
$(-1,5)$ & -0.016 & 0.030 & $0.047 * * *$ \\
& $(0.098)$ & $(0.130)$ & $(2.366)$ \\
$(-1,10)$ & -0.025 & 0.015 & $0.041^{* *}$ \\
& $(0.099)$ & $(0.124)$ & $(2.158)$ \\
\hline
\end{tabular}

Notes: CAR(-1,1) is the cumulative abnormal return from one day before to one day after the event. Political Patronage 1 separates firms based on political patronage as found in Faccio (2006) and Simon and Johnson (2003). Political Patronage 2 separates firms based on political patgronage as found in Faccio (2006) and Simon and Johnson (2003) and if firms are controlled by Khazanah Nasional Berhad, the investment holding arm of the Malaysian government. Standard deviations are given in parentheses for CARs, and $t$-Values are given in parentheses for the differences in CARs. 


\section{Table 2. Summary Statistics for Explanatory Variables}

Political Patronage 1

Firms with Political Patronage $\quad$ Firms without Political Patronage

\begin{tabular}{lccccc}
\hline & Mean & Std.Dev. & Mean & Std.Dev. & Difference \\
\hline Size & 6.286 & 1.693 & 4.526 & 1.563 & $1.761^{* * *}$ \\
ROA & 0.078 & 0.091 & 0.079 & 0.088 & 0.000 \\
TanAsset & 0.264 & 0.218 & 0.299 & 0.220 & -0.035 \\
Growth & 1.717 & 2.493 & 1.247 & 0.174 & $-0.470^{*}$ \\
Number of Firms & & & & 693 & \\
\hline
\end{tabular}

Political Patronage 2

Firms with Political Patronage Firms without Political Patronage

\begin{tabular}{lccccc}
\hline & Mean & Std.Dev. & Mean & Std.Dev. & Difference \\
\hline Size & 6.403 & 1.620 & 4.503 & 1.549 & $1.900^{* * *}$ \\
ROA & 0.090 & 0.107 & 0.078 & 0.087 & 0.011 \\
TanAsset & 0.272 & 0.218 & 0.299 & 0.220 & -0.026 \\
Growth & 1.762 & 2.338 & 1.240 & 1.746 & $0.522^{* *}$ \\
Number of Firms & & & & & \\
\hline
\end{tabular}

Notes: Size is the natural logarithm of total assets; ROA is the return on assets, measured as earnings before interest and taxes (EBIT) over total assets; Growth is measured as market value over book value; and Tangible Assets, is measured as net property, plant, and equipment over total assets. 
Table 3. Correlations among Dependent and Explanatory Variables

\begin{tabular}{|c|c|c|c|c|c|c|c|c|c|c|c|c|}
\hline & $\operatorname{CAR}(-1,1)$ & CAR $(-1,2)$ & $\operatorname{CAR}(-1,3)$ & $\operatorname{CAR}(-1,4)$ & CAR $(-1,5)$ & CAR $(-1,10)$ & $\begin{array}{c}\text { Political } \\
\text { Patronage } 1 \\
\end{array}$ & $\begin{array}{c}\text { Political } \\
\text { Patronage } 2 \\
\end{array}$ & Size & ROA & Growth & $\begin{array}{c}\text { Tangible } \\
\text { Assets }\end{array}$ \\
\hline $\operatorname{CAR}(-1,1)$ & 1.000 & & & & & & & & & & & \\
\hline $\operatorname{CAR}(-1,2)$ & 0.883 & 1.000 & & & & & & & & & & \\
\hline $\operatorname{CAR}(-1,3)$ & 0.838 & 0.905 & 1.000 & & & & & & & & & \\
\hline $\operatorname{CAR}(-1,4)$ & 0.752 & 0.809 & 0.889 & 1.000 & & & & & & & & \\
\hline $\operatorname{CAR}(-1,5)$ & 0.674 & 0.726 & 0.809 & 0.870 & 1.000 & & & & & & & \\
\hline CAR $(-1,10)$ & 0.597 & 0.646 & 0.702 & 0.751 & 0.782 & 1.000 & & & & & & \\
\hline Political Patronage 1 & -0.066 & -0.063 & -0.095 & -0.080 & -0.070 & -0.063 & 1.000 & & & & & \\
\hline Political Patronage 2 & -0.072 & -0.069 & -0.104 & -0.091 & -0.079 & -0.071 & 0.927 & 1.000 & & & & \\
\hline Size & -0.142 & -0.125 & -0.163 & -0.146 & -0.155 & -0.120 & 0.245 & 0.282 & 1.000 & & & \\
\hline $\mathrm{ROA}$ & 0.068 & 0.059 & 0.045 & 0.039 & 0.041 & 0.006 & -0.002 & 0.031 & -0.173 & 1.000 & & \\
\hline Growth & 0.008 & 0.019 & 0.013 & 0.027 & 0.016 & 0.033 & 0.059 & 0.070 & 0.107 & 0.482 & 1.000 & \\
\hline Tangible Assets & 0.094 & 0.082 & 0.120 & 0.119 & 0.111 & 0.133 & -0.035 & -0.029 & -0.025 & 0.033 & -0.023 & 1.000 \\
\hline
\end{tabular}

Notes: CAR(-1,1) is the cumulative abnormal return from one day before to one day after the event; Political Patronage 1 is a dummy variable that is equal to 1 if the firm is connected with top politicians following Simon and Johnson (2003) and 0 otherwise; Political Patronage 2 is a dummy variable that is equal to 1 if the firm is connected with top politicians following Simon and Johnson (2003) or is controlled by Khazanah Nasional Berhad, the investment holding arm of the Malaysian government, or 0 otherwise; Size is the natural logarithm of total assets; ROA is the return on assets, measured as earnings before interest and taxes (EBIT) over total assets; Growth, measured as market value over book value; and Tangible Assets, measured as net property, plant, and equipment over total assets. 
Table 4. Cumulative Abnormal Returns - Multivariate Regressions Political Patronage 1

\begin{tabular}{lcccc}
\hline & $(-1,1)$ & $(-1,3)$ & $(-1,5)$ & $(-1,10)$ \\
\hline \multirow{2}{*}{ Constant } & & & & \\
& $0.061^{* * *}$ & $0.071^{* * *}$ & $0085^{* * *}$ & $0.057^{* * *}$ \\
Patronage & $(3.80)$ & $(3.90)$ & $(4.23)$ & $(2.80)$ \\
Size & -0.094 & $-0.169^{* *}$ & $-0.248^{* * *}$ & $-0.232^{* * *}$ \\
& $(-1.50)$ & $(-2.38)$ & $(-3.14)$ & $(-2.79)$ \\
ROA & -0.007 & $-0.011 * * *$ & $-0.013^{* * *}$ & $-0.011^{* * *}$ \\
& $(-2.13)$ & $(-3.05)$ & $(-3.75)$ & $(3.31)$ \\
TanAsset & 0.071 & 0.021 & 0.014 & -0.047 \\
& $(1.09)$ & $(0.32)$ & $(0.28)$ & $(-0.89)$ \\
Growth & 0.039 & $0.055^{* * *}$ & $0.061^{* * *}$ & $0.071^{* * *}$ \\
Patronage*Size & $(2.50)$ & $(3.28)$ & $(3.28)$ & $(3.70)$ \\
& 0.000 & 0.003 & $0.004^{*}$ & $0.006 * * *$ \\
Patronage*ROA & $(0.22)$ & $(1.36)$ & $(1.73)$ & $(2.86)$ \\
& 0.011 & $0.023^{* *}$ & $0.031^{* * *}$ & $0.033^{* * *}$ \\
Patronage*TanAsset & $(1.29)$ & $(2.51)$ & $(3.10)$ & $(3.09)$ \\
& -0.048 & 0.068 & 0.341 & 0.094 \\
Patronage*Growth & $(-0.20)$ & $(0.25)$ & $(1.14)$ & $(0.27)$ \\
& 0.047 & 0.011 & 0.114 & 0.037 \\
& $(0.70)$ & $(0.87)$ & $(1.36)$ & $(0.42)$ \\
Industry Effect & 0.003 & -0.003 & -0.009 & 0.000 \\
Observations & $(0.44)$ & $(-0.43)$ & $(-0.99)$ & $(-0.04)$ \\
$R^{2}$ & & & & \\
\hline
\end{tabular}

Notes: This table presents the regression results of the effect of political patronage on cumulative abnormal returns (CARs). The dependent variables are short-term stock performance, measured with CARs using three different windows. Explanatory variables include: Political Patronage 1, a dummy variable that is equal to 1 if the firm is connected with top politicians following Simon and Johnson (2003) and 0 otherwise; Size, the natural logarithm of total assets; ROA, i.e. the return on assets, is measured as earnings before interest and taxes (EBIT) over total assets; Growth, measured as market value over book value; and Tangible Assets, measured as net property, plant, and equipment over total assets. Industry dummies are included but not reported. Robust $t$-statistics are given in parentheses. ${ }^{* * *},{ }^{* *}$, and ${ }^{*}$ denote significance at the $1 \%, 5 \%$, and $10 \%$ level, respectively. 
Table 5. Cumulative Abnormal Returns - Multivariate Regressions Political Patronage 2

\begin{tabular}{|c|c|c|c|c|}
\hline & $(-1,1)$ & $(-1,3)$ & $(-1,5)$ & $(-1,10)$ \\
\hline Constant & $\begin{array}{c}0.061^{* * *} \\
(3.78)\end{array}$ & $\begin{array}{c}0.071 * * * \\
(3.87)\end{array}$ & $\begin{array}{c}0.087^{* * *} \\
(4.27)\end{array}$ & $\begin{array}{c}0.058^{* * *} \\
(2.90)\end{array}$ \\
\hline Patronage & $\begin{array}{l}-0.097 \\
(-2.12)\end{array}$ & $\begin{array}{c}-0.163^{* *} \\
(-2.51)\end{array}$ & $\begin{array}{c}-0.242^{* * *} \\
(-3.36)\end{array}$ & $\begin{array}{c}-0.249 * * * \\
(-3.00)\end{array}$ \\
\hline Size & $\begin{array}{c}-0.007 * * \\
(-2.12)\end{array}$ & $\begin{array}{c}-0.011 * * * \\
(-3.01)\end{array}$ & $\begin{array}{c}-0.013^{* * *} \\
(-3.76)\end{array}$ & $\begin{array}{c}-0.011 \text { *** } \\
(-3.37)\end{array}$ \\
\hline $\mathrm{ROA}$ & $\begin{array}{l}0.079 \\
(1.18)\end{array}$ & $\begin{array}{l}0.029 \\
(0.42)\end{array}$ & $\begin{array}{l}0.021 \\
(0.42)\end{array}$ & $\begin{array}{l}-0.053 \\
(-0.96)\end{array}$ \\
\hline TanAsset & $\begin{array}{c}0.037 * * \\
(2.37)\end{array}$ & $\begin{array}{c}0.053^{* * *} \\
(3.15)\end{array}$ & $\begin{array}{c}0.057^{* * *} \\
(3.06)\end{array}$ & $\begin{array}{c}0.068^{* * *} \\
(3.56)\end{array}$ \\
\hline Growth & $\begin{array}{l}0.000 \\
(0.04)\end{array}$ & $\begin{array}{l}0.002 \\
(1.22)\end{array}$ & $\begin{array}{l}0.003 \\
(1.60)\end{array}$ & $\begin{array}{c}0.006^{* * *} \\
(2.80)\end{array}$ \\
\hline Patronage*Size & $\begin{array}{l}0.011 \\
(1.36)\end{array}$ & $\begin{array}{c}0.022 * * \\
(2.47)\end{array}$ & $\begin{array}{c}0.029 * * * \\
(2.99)\end{array}$ & $\begin{array}{c}0.034^{* * *} \\
(3.09)\end{array}$ \\
\hline Patronage*ROA & $\begin{array}{l}-0.133 \\
(-1.14)\end{array}$ & $\begin{array}{l}-0.079 \\
(-0.56)\end{array}$ & $\begin{array}{l}0.034 \\
(0.19)\end{array}$ & $\begin{array}{l}0.143 \\
(0.78)\end{array}$ \\
\hline Patronage*TanAsset & $\begin{array}{l}0.073 \\
(1.19)\end{array}$ & $\begin{array}{l}0.045 \\
(0.67)\end{array}$ & $\begin{array}{l}0.178 \\
(2.20)\end{array}$ & $\begin{array}{l}0.076 \\
(0.98)\end{array}$ \\
\hline Patronage*Grow th & $\begin{array}{l}0.006 \\
(1.83)\end{array}$ & $\begin{array}{l}0.001 \\
(0.25)\end{array}$ & $\begin{array}{l}0.001 \\
(0.11)\end{array}$ & $\begin{array}{l}-0.002 \\
(-0.34)\end{array}$ \\
\hline Industry Effect & YES & YES & YES & YES \\
\hline Observations & 732 & 732 & 732 & 732 \\
\hline $\mathrm{R}^{2}$ & 0.06 & 0.073 & 0.076 & 0.072 \\
\hline
\end{tabular}

Notes: This table presents the regression results of the effect of political patronage on cumulative abnormal returns (CARs). The dependent variables are short-term stock performance, measured with CARs using three different windows. Explanatory variables include: Political Patronage 2, a dummy variable that is equal to 1 if the firm is connected with top politicians following Simon and Johnson (2003) or is controlled by Khazanah Nasional Berhad, the investment holding arm of the Malaysian government, or 0 otherwise; Size, the natural logarithm of total assets; ROA, i.e. the return on assets, is measured as earnings before interest and taxes (EBIT) over total assets; Growth, measured as market value over book value; and Tangible Assets, measured as net property, plant, and equipment over total assets. Industry dummies are included but not reported. Robust $t$-statistics are given in parentheses. ${ }^{* *},{ }^{* *}$, and ${ }^{*}$ denote significance at the $1 \%, 5 \%$, and $10 \%$ level, respectively. 
Table 6. Change in Leverage - Multivariate Regressions

\begin{tabular}{|c|c|c|}
\hline & Political Patronage 1 & Political Patronage 2 \\
\hline \multirow[t]{2}{*}{ Constant } & $-0.065^{* * *}$ & $-0.066 * * *$ \\
\hline & $(-2.93)$ & $(-2.95)$ \\
\hline \multirow[t]{2}{*}{ Patronage } & $-0.204 * * *$ & $-0.168^{* *}$ \\
\hline & $(-2.92)$ & $(-1.99)$ \\
\hline \multirow[t]{2}{*}{ Size } & 0.005 & 0.004 \\
\hline & $(1.02)$ & $(0.97)$ \\
\hline \multirow[t]{2}{*}{ Leverage } & -0.036 & -0.033 \\
\hline & $(-0.52)$ & $(-0.45)$ \\
\hline \multirow[t]{2}{*}{ ROA } & $-0.287 *$ & $-0.285^{*}$ \\
\hline & $(-1.76)$ & $(-1.70)$ \\
\hline \multirow[t]{2}{*}{ TanAsset } & $0.083^{* * *}$ & $0.081 * * *$ \\
\hline & $(2.74)$ & $(2.62)$ \\
\hline \multirow[t]{2}{*}{ Growth } & $0.011 * *$ & $0.011 * *$ \\
\hline & $(2.16)$ & $(2.11)$ \\
\hline \multirow[t]{2}{*}{ Patronage*Size } & $0.023 * *$ & 0.021 \\
\hline & $(2.00)$ & $(1.58)$ \\
\hline \multirow[t]{2}{*}{ Patronage*Leverage } & 0.083 & -0.016 \\
\hline & $(0.56)$ & $(-0.13)$ \\
\hline \multirow[t]{2}{*}{ Patronage*ROA } & 0.455 & 0.200 \\
\hline & $(0.89)$ & $(0.86)$ \\
\hline \multirow[t]{2}{*}{ Patronage*TanAsset } & -0.100 & -0.051 \\
\hline & $(-0.88)$ & $(-0.55)$ \\
\hline \multirow[t]{2}{*}{ Patronage*Growth } & -0.006 & 0.000 \\
\hline & $(-0.40)$ & $(-0.03)$ \\
\hline Industry Effect & YES & YES \\
\hline Observations & 664 & 664 \\
\hline$R^{2}$ & 0.064 & 0.061 \\
\hline
\end{tabular}

Notes: This table presents the regression results of the effect of political patronage on capital structure and include financial firms. The dependent variable is $\Delta$ leverage, the difference in the average annual level of leverage three years after and three years before the 2008 election. The explanatory variables are: Size, the natural logarithm of total assets; ROA, i.e. the return on assets, is measured as earnings before interest and taxes (EBIT) over total assets; Tangible Assets, measured as net property, plant, and equipment over total assets; and Growth, measured as market value over book value; All explanatory variables are from the end of 2008. Industry dummies are included but not reported. Robust $t$-statistics are given in parentheses. ${ }^{* * *}, * *$, and $*$ denote significance at the $1 \%, 5 \%$, and $10 \%$ level, respectively. Political Patronage 1 separates firms based on political patronage as found in Simon and Johnson (2003). Political Patronage 2 separates firms based on political patronage as found in and Johnson (2003) and if firms are controlled by Khazanah Nasional Berhad, the investment holding arm of the Malaysian government. ***,**, and $*$ denote significance in the difference in the mean at the $1 \%, 5 \%$, and $10 \%$ level, respectively. 
Table 7. Change in Leverage - Multivariate Regressions without Financial Firms

Political Patronage $1 \quad$ Political Patronage 2

\begin{tabular}{lcc} 
Constant & $-0.072^{* * *}$ & $-0.072^{* * *}$ \\
Patronage & $(-2.77)$ & $(-2.77)$ \\
& $-0.241^{* * *}$ & $-0.183^{*}$ \\
Size & $(-2.89)$ & $(-1.72)$ \\
& 0.006 & 0.006 \\
Leverage & $(0.99)$ & $(0.91)$ \\
& -0.047 & $0.011^{* *}$ \\
ROA & $(-0.58)$ & $(-0.51)$ \\
& $-0.293^{*}$ & $-0.291^{*}$ \\
TanAsset & $(-1.74)$ & $(-1.67)$ \\
& $0.093^{* *}$ & $0.090^{* *}$ \\
Growth & $(2.60)$ & $(2.46)$ \\
Patronage*Size & $0.011^{* *}$ & $0.011^{* *}$ \\
& $(2.04)$ & $(1.98)$ \\
Patronage*Leverage & 0.026 & 0.026 \\
& $(1.13)$ & $(1.21)$ \\
Patronage*ROA & 0.058 & -0.082 \\
Patronage*TanAsset & $(0.27)$ & $(-0.53)$ \\
& 0.827 & 0.290 \\
Patronage*Growth & $(1.55)$ & $(1.22)$ \\
& -0.067 & -0.050 \\
Industry Effect & $(-0.43)$ & $(0-0.36)$ \\
Observations & -0.016 & -0.002 \\
& $(-0.99)$ & $(-0.26)$ \\
& & \\
& YES & 557 \\
& 557 & 0.066 \\
\hline
\end{tabular}

Notes: This table presents the regression results of the effect of political patronage on capital structure. The dependent variable is $\Delta$ leverage, the difference in the average annual level of leverage three years after and three years before the 2008 election. The explanatory variables are: Size, the natural logarithm of total assets; ROA, i.e. the return on assets, is measured as earnings before interest and taxes (EBIT) over total assets; Tangible Assets, measured as net property, plant, and equipment over total assets; and Growth, measured as market value over book value; All explanatory variables are from the end of 2008. Industry dummies are included but not reported. Robust $t$-statistics are given in parentheses. ${ }^{* * *}, * *$, and $*$ denote significance at the 1\%,5\%, and 10\% level, respectively. Political Patronage 1 separates firms based on political patronage as found in Simon and Johnson (2003). Political Patronage 2 separates firms based on political patronage as found in Simon and Johnson (2003) and if firms are controlled by Khazanah Nasional Berhad, the investment holding arm of the Malaysian government. ${ }^{* *},{ }^{* *}$, and ${ }^{*}$ denote significance in the difference in the mean at the $1 \%, 5 \%$, and $10 \%$ level, respectively. 
Table 8. Change in Debt Maturity - Multivariate Regressions

\begin{tabular}{|c|c|c|c|c|}
\hline & \multicolumn{2}{|c|}{ Change in Long-Term Debt } & \multicolumn{2}{|c|}{ Change in Short-Term Debt } \\
\hline & Political Patronage 1 & Political Patronage 2 & Political Patronage 1 & Political Patronage 2 \\
\hline \multirow[t]{2}{*}{ Constant } & $-0.028 *$ & $-0.028 *$ & $-0.038 *$ & $-0.038 *$ \\
\hline & $(-1.89)$ & $(-1.92)$ & $(-1.93)$ & $(-1.93)$ \\
\hline \multirow[t]{2}{*}{ Patronage } & $-0.163 * * *$ & $-0.152^{* * *}$ & -0.041 & -0.015 \\
\hline & $(-2.90)$ & $(-2.95)$ & $(-0.67)$ & $(-0.22)$ \\
\hline \multirow[t]{2}{*}{ Size } & 0.001 & 0.000 & -0.003 & 0.004 \\
\hline & $(0.37)$ & $(0.18)$ & $(0.90)$ & $(0.95)$ \\
\hline \multirow[t]{2}{*}{ Leverage } & $0.039 *$ & -0.034 & 0.003 & 0.001 \\
\hline & $(-1.72)$ & $(-1.48)$ & $(0.04)$ & $(0.02)$ \\
\hline \multirow[t]{2}{*}{ ROA } & $-0.076^{*}$ & $-0.068^{*}$ & -0.211 & -0.217 \\
\hline & $(-1.85)$ & $(-1.67)$ & $(-1.30)$ & $(-1.29)$ \\
\hline \multirow[t]{2}{*}{ TanAsset } & 0.027 & 0.023 & $0.056^{* *}$ & $0.058^{* *}$ \\
\hline & $(1.32)$ & $(1.14)$ & $(2.08)$ & $(2.07)$ \\
\hline \multirow[t]{2}{*}{ Growth } & $0.006^{* *}$ & $0.006^{* *}$ & 0.005 & 0.005 \\
\hline & $(2.23)$ & $(2.15)$ & $(1.04)$ & $(1.08)$ \\
\hline \multirow[t]{2}{*}{ Patronage*Size } & $0.020 * * *$ & $0.022^{* * *}$ & 0.003 & -0.001 \\
\hline & $(2.77)$ & $(2.78)$ & $(0.29)$ & $(-0.05)$ \\
\hline \multirow[t]{2}{*}{ Patronage*Leverage } & $0.200^{* *}$ & 0.102 & -0.117 & -0.119 \\
\hline & $(2.51)$ & $(1.31)$ & $(-0.74)$ & $(-0.93)$ \\
\hline \multirow[t]{2}{*}{ Patronage*ROA } & 0.041 & -0.155 & 0.413 & $0.355^{*}$ \\
\hline & $(0.16)$ & $(-1.36)$ & $(0.98)$ & $(1.88)$ \\
\hline \multirow[t]{2}{*}{ Patronage*TanAsset } & -0.120 & -0.054 & 0.020 & 0.003 \\
\hline & $(-1.78)$ & $(-0.84)$ & -0.200 & $(0.04)$ \\
\hline \multirow[t]{2}{*}{ Patronage*Growth } & -0.001 & 0.008 & -0.008 & -0.008 \\
\hline & $(0.16)$ & $(1.56)$ & $(-0.60)$ & $(-1.27)$ \\
\hline Industry Effect & YES & YES & YES & YES \\
\hline Observations & 664 & 664 & 664 & 664 \\
\hline Adjusted $R^{2}$ & 0.088 & 0.082 & 0.045 & 0.047 \\
\hline
\end{tabular}

Notes: This table presents the regression results of the effect of political patronage on short- and longterm debt. The dependent variables are $\Delta l t d$ and $\Delta s t d$, the difference in the average annual level of longand short-term debt over total assets three years after and three years before the 2008 election, respectively. The explanatory variables are: Size, the natural logarithm of total assets; ROA, i.e. the return on assets, is measured as earnings before interest and taxes (EBIT) over total assets; Tangible Assets, measured as net property, plant, and equipment over total assets; and Growth, measured as market value over book value; All explanatory variables are from the end of 2008. Industry dummies are included but not reported. Robust $t$-statistics are given in parentheses. $* * *, * *$, and $*$ denote significance at the $1 \%, 5 \%$, and $10 \%$ level, respectively. Political Patronage 1 separates firms based on political patronage as found in Simon and Johnson (2003). Political Patronage 2 separates firms based on political patronage as found in Simon and Johnson (2003) and if firms are controlled by Khazanah Nasional Berhad, the investment holding arm of the Malaysian government. ***,**, and * denote significance in the difference in the mean at the $1 \%, 5 \%$, and $10 \%$ level, respectively. 
Table 9. Change in Debt Maturity - Multivariate Regressions without Financial Firms

\begin{tabular}{|c|c|c|c|c|}
\hline & \multicolumn{2}{|c|}{ Change in Long-Term Debt } & \multicolumn{2}{|c|}{ Change in Short-Term Debt } \\
\hline & Political Patronage 1 & Political Patronage 2 & Political Patronage 1 & Political Patronage 2 \\
\hline \multirow[t]{2}{*}{ Constant } & $-0.069 * * *$ & -0.025 & $-0.045^{* *}$ & $-0.047 * *$ \\
\hline & $(-2.93)$ & $(-1.61)$ & $(-1.93)$ & $(-1.97)$ \\
\hline \multirow[t]{2}{*}{ Patronage } & $-0.142 * *$ & $-0.145^{* *}$ & -0.100 & -0.038 \\
\hline & $(-2.23)$ & $(-2.44)$ & $(-1.16)$ & $(-0.38)$ \\
\hline \multirow[t]{2}{*}{ Size } & 0.000 & -0.001 & 0.006 & 0.007 \\
\hline & $(-0.08)$ & $(-0.39)$ & $(1.10)$ & $(1.16)$ \\
\hline \multirow[t]{2}{*}{ Leverage } & -0.017 & -0.009 & -0.030 & -0.034 \\
\hline & $(-0.80)$ & $(-0.42)$ & $(-0.37)$ & $(-0.40)$ \\
\hline \multirow[t]{2}{*}{$\mathrm{ROA}$} & $-0.081 *$ & $-0.072 *$ & -0.212 & -0.218 \\
\hline & $(-1.90)$ & $(-1.72)$ & $(-1.27)$ & $(1.27)$ \\
\hline \multirow[t]{2}{*}{ TanAsset } & 0.023 & 0.018 & $0.070^{* *}$ & $0.072^{* *}$ \\
\hline & $(1.16)$ & $(0.93)$ & $(2.14)$ & $(2.12)$ \\
\hline \multirow[t]{2}{*}{ Growth } & $0.007 * *$ & $0.006^{* *}$ & 0.004 & 0.004 \\
\hline & $(2.09)$ & $(2.01)$ & $(0.83)$ & $(0.89)$ \\
\hline \multirow[t]{2}{*}{ Patronage*Size } & 0.014 & $0.022^{*}$ & 0.012 & 0.004 \\
\hline & (1.18) & $(1.83)$ & $(0.69)$ & $(0.25)$ \\
\hline \multirow[t]{2}{*}{ Patronage*Leverage } & 0.151 & 0.027 & -0.092 & -0.109 \\
\hline & $(1.45)$ & $(0.30)$ & $(-0.42)$ & $(-0.72)$ \\
\hline \multirow[t]{2}{*}{ Patronage*ROA } & 0.053 & -0.168 & 0.774 & $0.458^{* *}$ \\
\hline & $(0.20)$ & $(-1.65)$ & $(1.41)$ & $(2.20)$ \\
\hline \multirow[t]{2}{*}{ Patronage*TanAsset } & 0.023 & -0.003 & -0.048 & -0.047 \\
\hline & $(1.16)$ & $(-0.03)$ & $(-0.40)$ & $(-0.47)$ \\
\hline \multirow[t]{2}{*}{ Patronage*Growth } & 0.002 & $0.008^{*}$ & -0.018 & -0.01 \\
\hline & $(0.27)$ & $(1.80)$ & $(-1.12)$ & $(-1.60)$ \\
\hline Industry Effect & YES & YES & YES & YES \\
\hline Observations & 557 & 557 & 557 & 557 \\
\hline Adjusted $R^{2}$ & 0.087 & 0.086 & 0.052 & 0.052 \\
\hline
\end{tabular}

Notes: This table presents the regression results of the effect of political patronage on short- and longterm debt. The dependent variables are $\Delta l t d$ and $\Delta s t d$, the difference in the average annual level of longand short-term debt over total assets three years after and three years before the 2008 election, respectively. The explanatory variables are: Size, the natural logarithm of total assets; ROA, i.e. the return on assets, is measured as earnings before interest and taxes (EBIT) over total assets; Tangible Assets, measured as net property, plant, and equipment over total assets; and Growth, measured as market value over book value; All explanatory variables are from the end of 2008. Industry dummies are included but not reported. Robust $t$-statistics are given in parentheses. ${ }^{* *},{ }^{* *}$, and ${ }^{*}$ denote significance at the $1 \%, 5 \%$, and $10 \%$ level, respectively. Political Patronage 1 separates firms based on political patronage as found in Simon and Johnson (2003). Political Patronage 2 separates firms based on political patronage as found in Simon and Johnson (2003) and if firms are controlled by Khazanah Nasional Berhad, the investment holding arm of the Malaysian government. ***,**, and ${ }^{*}$ denote significance in the difference in the mean at the $1 \%, 5 \%$, and $10 \%$ level, respectively. 